Rapid Reviews COVID-19

\title{
Reviews of "LOW BIRTH WEIGHT AS A RISK FACTOR FOR SEVERE COVID-19 IN ADULTS"
}

Stephanie Eick ${ }^{1}$, Naida Gaber ${ }^{2}$, Anders Hviid ${ }^{3}$

${ }^{1}$ University of California San Francisco, Obstetrics, Gynecology and Reproductive Sciences, 2University of California, San Francisco,

${ }^{3}$ Professor, Statens Serum Institut, Department of Epidemiology Research, Denmark

Published on: Dec 02, 2020

DOI: $10.1162 / 2 \mathrm{e} 3983 f 5.139525 \mathrm{c} 1$

License: Creative Commons Attribution 4.0 International License (CC-BY 4.0). 
To read the original manuscript, click the link above.

Summary of Reviews: This study suggests that low birth weight (LBW) could be a risk factor for severe COVID-19. Reviewers found that the methods employed were not rigorous to support this conclusion, and there remains a more complex relationship between LBW and adverse pulmonary outcomes.

\section{Reviewer 1 (Stephanie Eick, Naida Gaber) |}

Reviewer 2 (Anders Hviid)

$$
\begin{aligned}
& \text { RR:C19 Strength of Evidence Scale Key. } \\
& \text { प्रमप = Misleading } \\
& \text { प्र००० = Not Informative } \\
& \text { प्रा पि = Potentially Informative }
\end{aligned}
$$

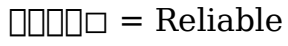

$$
\begin{aligned}
& \text { प्राप्र = Strong }
\end{aligned}
$$

To read the reviews, click the links below. 